\title{
Discovery Learning using Multiple Representation model for enhancing scientific processing and critical thinking skills of the students
}

\author{
Syahmel Syahmel *, Jumadi Jumadi \\ Department of Science Education, Program Pascasarjana, Universitas Negeri Yogyakarta. \\ Jalan Colombo No. 1, Karangmalang, Yogyakarta 55281, Indonesia. \\ * Corresponding Author. E-mail: syahmelkune@gmail.com
}

Received: 16 August 2019; Revised: 23 August 2019; Accepted: 3 October 2019

\begin{abstract}
The particular study aimed to reveal: (1) the feasibility of the developed Discovery Learning using Multiple Representations (DLMRs) model on the subject matter "Substance Pressure and its Application in Daily Life" for grade 8 students of SMP, (2) the practicality of the developed DLMRs model for science teachers and grade 8 students of SMP, and (3) the effectiveness of the developed DLMRs model in improving the science process and critical thinking skills of grade 8 students of SMP. This research was research and development, adapting the development procedures by Borg \& Gall which consisted of 10 steps: (1) research and information collection, (2) planning, (3) developing the preliminary form of product, (4) preliminary field testing, (5) main product revision, (6) main field testing, (7) operational product revision, (8) operational field testing, (9) final product revision, and (10) dissemination and implementation. The limited trial subjects consisted of 15 students of class VIII.4 SMPN 1 Watopute. The subjects of the field trial in the experimental class consisted of 31 students of class VIII.1, and in control, the class consisted of 32 students of class VIII.3 SMPN 1 Watopute. The sampling technique was cluster sampling. The instrument of data collection was an essay test to measure critical thinking skills, observation sheets to measure science process skills, questionnaires to determine the readability of the DLMRs student worksheet, and questionnaires to determine student and teacher responses to DLMRs model. The data analysis technique was the MANOVA test with a significance level of 0.05 . The results showed that: (1) the developed DLMRs model was feasible to implement based on experts judgment, (2) the DLMRs model was practical for teaching science based on responses given by teachers and students, (3) the DLMRs model was effective for improving students' science process and critical thinking skills.
\end{abstract}

Keywords: DLMRs model; science process skills; critical thinking skills.

How to Cite: Syahmel, S., \& Jumadi, J. (2019). Discovery Learning using Multiple Representation model for enhancing scientific processing and critical thinking skills of the students. Jurnal Inovasi Pendidikan IPA, 5(2), 180-194. doi:https://doi.org/10.21831/jipi.v5i2.26704

do https://doi.org/10.21831/jipi.v5i2.26704

\section{INTRODUCTION}

Science is a systematic effort to understand natural phenomena. Human beings who are endowed with curiosity, lead to an effort always to investigate to get a proper description of natural phenomena. Natural Science (IPA) is a tool designed to facilitate the needs of the student in developing scientific knowledge. The main purpose of learning science is to create individuals who have good scientific literacy, innovative, and using scientific knowledge to make decisions and solve problems.

The characteristics of science learning require the student to have descriptive, procedural, and declarative abilities. Then, the teacher should have a good preparation for the purpose the students can well understand the concept of science thoroughly related to the characteristics of science. Learning science not only understands the concepts through memorization descriptively but also the abstract science concepts. The illustration, before understanding the concept becomes the obligation of the teacher to help and bridge students. Concepts or problems in learning science sometimes require students to transform verbal writing into other forms, such as pictures or diagrams, before they solve mathematically and well understood. These phenomena become a problem for students to comprehend the concept of science comprehensively, also a challenge for the teacher. A recommendation from the National Science Teachers Association (NSTA) regarding General Skills of Teaching (teaching skills) is, 
the learning of science concepts should deliver to students in various ways (National Science Teachers Association, 2003). Learning certain concepts should involve multiple interactions with various characteristics. Some concepts must be integrated into a network of concepts that are coherent with others to make the correct decision. A teacher is obliged to provide learning opportunities for students with multiple interactions of a concept in various contexts, as well as through various ways in order the student can give an appropriate interpretation of the concepts (National Science Teachers Association, 2003).

Each student has a different interpretation when solving the concepts in science learning as a different ability of the internal interpretation of student. Their prior knowledge or experience supports the ability of the student to interpret a concept. Various cases and abstract concepts in science make difficult students interpret when they only use the ability of internal interpretation emerging from their minds. The internal interpretation skills must be supported by the ability of external representation related to the real world or the surrounding environment to facilitate the students in gaining the knowledge through the thinking process and consider the information they will have (Treagust, Duit, \& Fischer, 2017). This external interpretation used to communicate ideas, concepts or natural phenomena in science learning to help students are developing internal representations (Pierce, Stacey, Wander, \& Ball, 2011, p. 96).

Students who can use more than one representation in understanding a science concept will easier understand the concept. This ability is known as multiple representations. A student should have this ability in science learning to complete cognitive processes, limit the possibility of misinterpretation, and strengthen depth understanding of a situation (S. E. Ainsworth, Bibby, \& Wood, 1997, pp. 37-41) Science learning emphasizes the problem-solving process that requires scientific skills to carry out an investigation or experiment. The scientific skills are the science process skills and manipulative skills. Also, the process of science learning requires thinking skills to integrate knowledge, skills, and attitudes as an effort to understand the environment. Teaching and learning processes that apply thinking skills are the foundation for meaningful learning. Thinking skills consist of two, namely critical thinking skills and creative thinking skills. Meaningful learning will be achieved if students have a dominant role during learning activities in class. Learning activities should be organized to create opportunities for students to maximize thinking skills to conceptualize, solve problems and make decisions.

Besides, emphasis on scientific skills and thinking skills, also, need to design a learning environment that able for leading students to experience meaningful learning. The principles of learning activities according to the Ministry of Education Regulation, Number 81A of 2013, are student-centred, and teachers only play as facilitators (Menteri Pendidikan dan Kebudayaan Republik Indonesia, 2013). Each student must seek and construct their knowledge through a series of learning. A teacher in bridging the students to understand a concept needs to manipulate learning material following the level of cognitive development of students. The main purpose of this manipulation is to mediate while optimizing the way students think (Hosnan \& Sikumbang, 2014, p. 283).

The material taught by teachers in science learning is the integration of several fields of study, such as physics, chemistry, and biology. The concepts of learning science also strongly relate and often find in everyday life. Each concept or material has characteristics and difficulties. "Substance Pressure and Its Application in Everyday Life" is an example of the material of science that often found by students in the environment. The concepts are widely applied in daily activities. Another characteristic is, that, to understand the concepts of this material, learning models and approaches must optimize the students' scientific process skills and critical thinking. This material also requires the use of multiple representations to lead to a comprehensive understanding of the concepts.

Regarding the results of The Trends in International Mathematics and Science Study (TIMSS) in 2015 provided an overview of students 'abilities at four levels referring to the International Science Benchmarks, the percentage of the majority of Indonesian students' abilities are at the low level (Provasnik et al., 2016). Each level in the International Science Benchmarks, namely advanced, high, intermediate and low, has indicators that provide information on the standard of student's scientific abilities. The Republic of Indonesia occupies the 3rd lowest position out of the 52 countries participating in the international education achievement evaluation program, which is held every four years. Indonesian students with an average age of 10 years who took part in this program, only obtain- 
ed 1 point at the advanced level of 625 maximum points. Some indicators of advanced levels are independence demonstrating basic knowledge and skills related to inquiry, understanding how experimental activities, interpreting the results of investigations, giving reasons, making conclusions based on descriptions and diagrams, evaluating and supporting arguments (Provasnik et al., 2016). Based on the result of TIMSS on 2015 obtained by Indonesian students, it showed the low score of students in science process skill and critical thinking of understanding the science concept on the advanced level.

The result of the Survey of the Program for International Student Assessment (PISA) in 2015 conducted by the Organization for Economic Cooperation and Development (OECD) showed that the science performance of Indonesian students is at the level below (OECD, 2014). The level below is constant from 2006 to 2015. In 2015, Indonesia occupies the lowest top 10 positions, which is ranked 63 out of 72 countries participating in PISA. PISA used 6 levels of indicators in assessing the students' scientific abilities. Indicators of science performance included science process skills and critical thinking, such as classifying, data interpreting, predicting, hypothesizing, experimenting, and evaluating-students' knowledge of science in daily life also used in the assessment. Assessment criteria at the intermediate to advanced levels are each student required to have an understanding of scientific concepts of abstract, can explain natural phenomena, and can interpret data of images, diagrams or mathematical. Based on the results of this PISA survey, it concluded that the science process skills and critical thinking of Indonesian students are low.

A preliminary study was conducted at Watopute 1 Public Middle School by providing questionnaires to 2 science teachers to find out the understanding of science concepts, science process skills, and critical thinking skills of students that are taught with usual models and methods used by teachers in the classroom. The results show a low score on these aspects. According to the teacher, the ability to interpret data which is an aspect of science process skills is very low. The use of multiple representations is also less emphasized by the teacher, so, it affects the low ability of students in interpreting the concepts of science they receive. Students sometimes can interpret concepts through images, but they are unable to interpret concepts or interpret them into diagrams or graphs before solving the concept through mathematical equa- tions. The methods commonly used by teachers are lecturing and discussions, as well as teachers lacking in providing variation in the learning process. As a result, not all students are motivated and understand the material provided. The use of lecturing methods can also reduce students' curiosity about the material being taught because the teacher dominates the lesson. The low critical thinking skills of students at Watopute 1 Public Middle School were also shown through the results of tests given to 26 students in grade IX. The average score of students on the essay, on aspects of critical thinking skills, such as classifying, evaluating and analyzing the material Pressure Substance, is 59.6. The highest score is 75.5 which only one student obtained the score. Meanwhile, the lowest score is 40 . The results of the preliminary study at Watopute 1 Middle School, is fully attached in Appendix 10.

Answering to various facts and problems of the science learning process in improving science process skills and critical thinking skills of students, the solution offered to solve this problem is the selection of models, methods, strategies or learning approaches with learning paradigms that emphasize the dominance or activeness of students in learning (studentcentred learning). The discovery learning model is a learning model that assumes able to accommodate all of these aspects. Discovery learning is a model that encourages the active involvement of each student to find the concepts and principles independent or in groups, through prepared problems provided by the teacher. The teacher's task in this model is only as guidance with a few roles in bridging students to find concepts and principles according to the determined goal.

The discovery learning model is integrated or using multiple representations which act as approaches in a learning activity. The result of modification is a new learning model, called the Discovery Learning model using multiple Representations (DLMRs). The characteristic of this model is the use of multiple representations into the syntax of the discovery learning model. The purpose of this modification is to create a student's comprehension of the concept of science comprehensively by utilizing and optimizing multiple representations. Students who learn through discovery learning models will certainly use science process skills, while multiple representations have the function to complete and explore concepts in-depth, as well as anticipate misinterpretation of the data or information obtained. So, it trains them always to do critical 
thinking. The science learning model using discovery learning followed directly by multiple representations is expected able answering and facilitating the demands of learning science that is descriptive, procedural, declarative, and abstract. Students who can learn science in this context will greatly affect the improvement of concept understanding, science process skills, and critical thinking skills.

Based on various studies of problems and challenges, the article aims to research developing a new science learning model, which is the Discovery Learning model using Multiple Representations (DLMRs). The particular study aims to: (1) determine the feasibility of the DLMRs model on the material of Substance Pressure and its Application in Daily Life for ninth-grade students of junior high school; (2) find out the practicality the developed of DLMRs model for science teachers as well as ninth-grade students in junior high schools; and 3) determine the effectiveness of the DLMRs model in improving science process skills and critical thinking of ninth-grade students in junior high school.

\section{METHOD}

\section{Model and Procedure of Development}

The product development procedure in this study adopted the Borg and Gall development model (Gall, Gall, \& Borg, 2007), which consisted of 10 steps and presented in Figure 1.

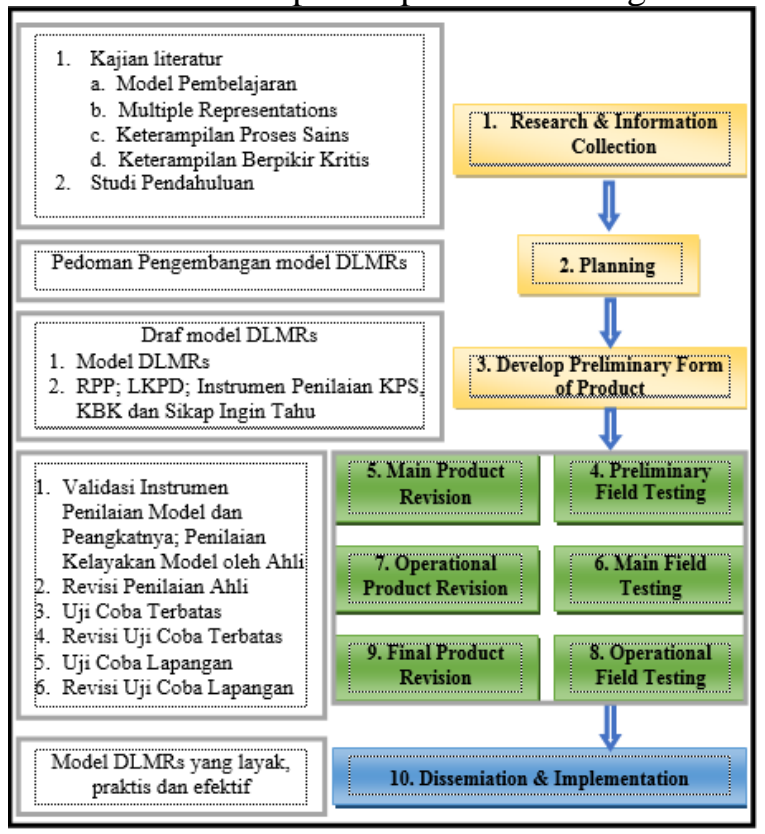

Figure 1. The procedure of Development Model of DLMRs

\section{Design of Trial}

Limited Trial

The limited trial aims to see the learning activity in the classroom using the DLMRs model and the readability of the LKPD model of the DLMRs.

\section{Field Trial}

The field trial carried out on a larger scale using a quasi-experimental design, i.e. nonequivalent pretest-posttest control-group design, presented in Table 1.

Table 1. Design of Nonequivalent PretestPosttest Control-Group

\begin{tabular}{clccc}
\hline No. & Group & Pretest & Treatment & Posttest \\
\hline 1. & Experiment & $\mathrm{O}_{1}$ & $\mathrm{X}_{\mathrm{E}}$ & $\mathrm{O}_{2}$ \\
2. & Control & $\mathrm{O}_{3}$ & $\mathrm{X}_{\mathrm{K}}$ & $\mathrm{O}_{4}$ \\
\hline
\end{tabular}

Where:

O1: Preliminary measurement in the experimental class

O2: final measurement in the experimental class

O3: Preliminary measurement in the control class

O4: final measurements in the control class

XE: treatment in the experimental class (learning using DLMRs model)

$\mathrm{XK}$ : treatment in the control class (learning using scientific approach K13)

\section{Test Subject}

The subject of the limited trials was from class VIII.4 at SMP 1 Watopute, which consisted of 15 students. Subjects of Field trials were determined using cluster sampling techniques. The field trial subjects were from 2 classes, out of 5 classes, which were class VIII.1 with 31 students as experimental class and class VIII.3 with 32 students as control class.

\section{Data Collection Instruments}

Data collection instruments consisted of (1) the feasibility assessment sheet for DLMRs model, (2) the feasibility assessment sheet of the Lesson Plan of DLMRs model, (3) feasibility assessment sheet of the LKPD DLMRs model; (4) readability questionnaire of the LKPD model LKPD, (5) teacher questionnaire responses to the DLMRs model, (6) student questionnaire responses to the DLMRs model, (7) essay test of critical thinking skills; and (8) observation sheet of science process skills. 


\section{Jurnal Inovasi Pendidikan IPA, 5 (2), 2019 - 185}

Syahmel Syahmel, Jumadi Jumadi

\section{Data Analysis Technique}

The quality of the developed product was determined by changing the score of the results the assessment of the DLMRs model along with supporting instruments, which were originally the form of quantitative scores which are converted into five-scale qualitative (interval) data. Changes to the interval data, as stated by (Widoyoko, 2013, p. 238) presented in Table 2. Determination of the interval criteria also used to determine the practicality of the DLMRs model through obtained data from responses given by teachers and students after learning using the DLMRs model. Analysis to determine the effectiveness of the DLMRs model used the gain score and the MANOVA test. The mean gain score was then categorized using Table 3 . Based on Table $3, X$ is an empirical score, $\overline{X_{i}}$ is the ideal mean $(1 / 2$ (maximum score + minimum score $))$, and $S b_{i}$ is the ideal standard deviation (1/6 (score maximum-minimum score)).

Table 2. Determination of Product Criteria Intervals

\begin{tabular}{cll}
\hline No. & \multicolumn{1}{c}{ Score of Interval } & Category \\
\hline 1. & $X>\left(\bar{X}_{i}+1,8 S b_{i}\right)$ & Excellent \\
2. & $\left(\bar{X}_{i}+0,6 S b_{i}\right)<X \leq\left(\bar{X}_{i}+1,8 S b_{i}\right)$ & Good \\
3. & $\left(\bar{X}_{i}-0,6 S b_{i}\right)<X \leq\left(\bar{X}_{i}+0,6 S b_{i}\right)$ & Medium \\
4. & $\left(\bar{X}_{i}-1,8 S b_{i}\right)<X \leq\left(\bar{X}_{i}-0,6 S b_{i}\right)$ & Poor \\
5. & $X \leq\left(\bar{X}_{i}-1,8 S b_{i}\right)$ & Very Poor \\
\hline
\end{tabular}

Table 3. Category of Gain Score

\begin{tabular}{cll}
\hline No. & \multicolumn{1}{c}{ Gain Score $(g)$} & \multicolumn{1}{c}{ Category } \\
\hline 1. & $g>0,7$ & High \\
2. & $0,7 \geq g \geq 0,3$ & Intermediate \\
3. & $g<0,3$ & Low \\
\hline
\end{tabular}

\section{RESULT AND DISCUSSION}

\section{Result}

\section{Research and Information Collection}

The research and information collection phase aims to find and identify the clarity of information from the research object. Literature study aims to examine the studies relating to science process skills, critical thinking skills, and the importance of learning and enhancing these two skills in learning science. The literature review also carried out to understand the science learning models that are effective in developing science process skills and critical thinking, and facilitating learning of science that is descriptive, procedural, and declarative as well. Preliminary studies conducted to support the literature review. The preliminary study was through providing a questionnaire to science teachers to find out the effectiveness of learning models commonly used by teachers in the classroom and to identify student's KPS and KBK when they learn with models or methods that commonly often used by teachers in the classroom.

Planning

This planning phase produces a guideline for developing the DLMRs model and its supporting tools based on information collected at the information collecting stage.

\section{Develop Preliminary Form of Product}

This stage produces a draft of the DLMRs model based on the results of collecting information from literature studies and preliminary studies. The draft of the developed DLMRs model consisted of explanations of each element that must be in a learning model, as suggested by (Joyce, Weil, \& Calhoun, 2014). The description of the elements of the DLMR model is as follows.

\section{Theoretical Review}

The development of the DLMRs model is based on several learning theories that support the use of discovery learning models, and experts' studies on the importance of using multiple representations in learning science. The DLMRs model was developed based on the constructivism theory. There are three theories as to the basis for developing the particular model of DLMRs, namely the theories of Piaget, Vygotsky and Bruner. Piaget's cognitive development theory is a theory that underlies the development of this model because students will construct their knowledge through organizing (assimilation and accommodation) concepts in learning with experimental methods. And, through this model, students are expected to have a confident attitude, and, achieved the equilibrium in their cognitive structure (Crain, 2015). The DLMRs model will help assimilate or accommodate student knowledge. Assimilation is expected to occur when the teacher provides the phenomenon at the beginning of learning. Then, it continued to do experiments and matched with the experiences they have. Students who feel incompatible with the result of the experiment with prior knowledge are expected to be accommodated through the use of multiple representations. So, the students feel 
confident and can change the wrong knowledge from previous experiences.

Vygotsky's theory in learning-centres is on: (a) students actively build knowledge; (b) learning is in the zone of proximal development; and (c) development always relates to social interaction (Goldston \& Downey, 2013). The characteristics of learning activities according to Vygotsky's theory became the foundation in the development of the DLMRs model because it encourages social interaction as well as the dominant role of students in the learning process in the classroom. The implementation of the DLMRs model in learning science creates a dominant social interaction among students in the classroom. So, this model divides students into groups in performing experiments. The purpose of this model is to create a learning environment with cooperation between students in the group to understand concepts or materials based on their experience during the experimental activities.

Bruner with the theory of free discovery learning argues that teaching and learning activities will run effectively when the teacher can provide a learning environment for students to take the maximum role to find and construct an understanding of concepts through discovery. Bruner argues three stages that determine a person's cognitive development through an environment, namely enactive, iconic, and symbolic (Budiningsih, 2005, p. 43). The discovery of the concept independently and the influence of the environment on cognitive development, on Bruner's view, was used as a theoretical basis for developing models of DLMRs in the particular study. The DLMR model emphasizes the active role of students in discovering science concepts with minimal guidance from the teacher.

\section{Syntax}

(Joyce et al., 2014, p. 104; Trianto, 2010, p. 97) stated that syntax is a practical structure that must be in a learning model as a guide both for teacher and student in learning activities in the class. The syntax of the DLMRs model is a modification of the syntax of the discovery learning model and the learning steps in using multiple representations described descriptively by (S. E. Ainsworth et al., 1997, pp. 37-41; S. Ainsworth, 1999, pp. 131-134; Sprianus, Sutopo, $\&$ Parno, 2016). The modification is the use of multiple representations that engage each syntax of the discovery learning model, presented in Table 4. The purpose of the modification is to make comprehension within students toward the science concept comprehensively by using and optimizing multiple representations.

\section{Social system}

(Joyce et al., 2014) defines the social system as a picture of the role or reciprocal relationship between educators and students, or among fellow students in the classroom. The DLMRs model has a social system design that encourages teachers as facilitators in learning. Organizing the class in this model is conducted by distributing students into several study groups, consisting of 4 to 5 students in each group. In the Planning_V, Stimulation_V and Problem Statement_V, interactions are still dominated by the teacher. At the stage of Internalization_VGFM (data collection and processing) and Verification_VGFM, interaction is dominated by students in groups, either in experiment activity or completing tasks in LKPD. Meanwhile, the role of the teacher is a few, which only looks around to determine the difficulty of the group during the experiment. At the stage of Generalization_VGFM, the teacher mere have a role in concluding the learning.

\section{Principles of Reaction}

Hamid (2011, p. 8) stated the principle of reaction is a form of teaching activity in seeing and treating students. The principles of reaction in the DLMRs model are; (a) teacher provide phenomena or events either from the environment around or students' experience from previous learning; (b) teacher use communicative language and easy to understand by student when providing information; (c) teacher give opportunity to student to ask questions about the phenomena; (d) teacher gives opportunity to student to think and argue the arguments; (e) teacher supports the hypothesis and create discussion as a forum for students to test hypotheses; (f) teacher provides as less as assistance to students during experiment activity and completing tasks in LKPD; (g) teacher provides a comfortable learning atmosphere for students in interacting with others; (h) teacher helps students discuss and evaluate strategies/ways of thinking in understanding the concept of science.

\section{Supporting System}

The support system for the DLMRs model consists of Lesson Plan (RPP) of the DLMRs model, Student Worksheet (LKPD) of the 
DLMRs model, KPS observation sheet, and KBK description test.

Effect

The effect of the implementation of the DLMRs model consists of instructional effect (KPS and KBK) and accompaniment effect (curiosity).

Preliminary Field Testing

This stage aims to validate all assessment instruments and to assess the feasibility of the developed product. The content validity of the
KBK and KPS assessment instruments for students was estimated through the Aiken's V formula which based on the assessment of 2 experts using five scales categories. The results of the analysis of Aiken's V coefficient for each item about the KBK essay and the KPS statement item are in the high-value range, which is 0.88 to 1. It means the instruments of KBK and KPS assessment have good content validity. The results of the feasibility assessment of the DLMRs, RPP, and LKPD of the DLMRs models are presented in Table 5, Table 6 and Table 7.

Table 4. Syntax of DLMRs Model

\begin{tabular}{lll}
\hline Discovery Learning Model & Description of Ainsworth \& Sprianus & DLMRs Model \\
\hline Planning & Orientation & Planning_V \\
Stimulation & Exploration & Stimulation_V \\
Problem Statement & & Problem Statement_V \\
$\begin{array}{l}\text { Data Collection/Finding } \\
\text { Data Processing }\end{array}$ & Internalization & Internalization_VGFM \\
Verification & & \\
Generalization & Evaluation & Verification_VGFM \\
- & & Generalization_VGFM \\
\hline
\end{tabular}

Table 5. Result of Feasibility Assessment of DLMRs Model

\begin{tabular}{|c|c|c|c|c|}
\hline No. & Aspect & Interval Score & Score & Quality \\
\hline 1. & Theoretical Review & $\begin{array}{l}X>7,2 \\
5,4<X \leq 7,2 \\
3,6<X \leq 5,4 \\
1,8<X \leq 3,6 \\
X \leq 1,8\end{array}$ & 9 & Excellent \\
\hline 2. & Syntax & $\begin{array}{l}X>7,2 \\
5,4<X \leq 7,2 \\
3,6<X \leq 5,4 \\
1,8<X \leq 3,6 \\
X \leq 1,8\end{array}$ & 9 & Excellent \\
\hline 3. & Social System & $\begin{array}{l}X>2,4 \\
1,8<X \leq 2,4 \\
1,2<X \leq 1,8 \\
0,6<X \leq 1,2 \\
X \leq 0,6\end{array}$ & 3 & Excellent \\
\hline 4. & Principle of Reaction & $\begin{array}{l}X>4,8 \\
3,6<X \leq 4,8 \\
2,4<X \leq 3,6 \\
1,2<X \leq 2,4 \\
X \leq 1,2\end{array}$ & 6 & Excellent \\
\hline 5. & Supporting System & $\begin{array}{l}X>5,6 \\
4,2<X \leq 5,6 \\
2,8<X \leq 4,2 \\
1,4<X \leq 2,8 \\
X \leq 1,4\end{array}$ & 7 & Excellent \\
\hline 6. & Effect & $\begin{array}{l}X>1,6 \\
1,2<X \leq 1,6 \\
0,8<X \leq 1,2 \\
0,4<X \leq 0,8 \\
X \leq 0,4\end{array}$ & 2 & Excellent \\
\hline
\end{tabular}


Jurnal Inovasi Pendidikan IPA, 5 (2), 2019 - 188

Syahmel Syahmel, Jumadi Jumadi

Table 6. Results of the feasibility assessment the Lesson Plan of DLMRs Model

\begin{tabular}{|c|c|c|c|c|}
\hline No. & Aspect & Interval Score & Score & Quality \\
\hline 1. & Identity of RPP & $\begin{array}{l}X>4 \\
3<X \leq 4 \\
2<X \leq 3 \\
1<X \leq 2 \\
X \leq 1\end{array}$ & 5 & Excellent \\
\hline 2. & Formulation of Indicators and Learning Goal & $\begin{array}{l}X>2,4 \\
1,8<X \leq 2,4 \\
1,2<X \leq 1,8 \\
0,6<X \leq 1,2 \\
X \leq 0,6\end{array}$ & 3 & Excellent \\
\hline 3. & Material & $\begin{array}{l}X>2,4 \\
1,8<X \leq 2,4 \\
1,2<X \leq 1,8 \\
0,6<X \leq 1,2 \\
X \leq 0,6\end{array}$ & 3 & Excellent \\
\hline 4. & Learning Method & $\begin{array}{l}X>4 \\
3<X \leq 4 \\
2<X \leq 3 \\
1<X \leq 2 \\
X \leq 1\end{array}$ & 5 & Excellent \\
\hline 5. & Media and Learning Resources & $\begin{array}{l}X>2,4 \\
1,8<X \leq 2,4 \\
1,2<X \leq 1,8 \\
0,6<X \leq 1,2 \\
X \leq 0,6\end{array}$ & 3 & Excellent \\
\hline 6. & The Steps of Learning & $\begin{array}{l}X>5,6 \\
4,2<X \leq 5,6 \\
2,8<X \leq 4,2 \\
1,4<X \leq 2,8 \\
X \leq 1,4\end{array}$ & 7 & Excellent \\
\hline 7. & Assessment of Learning & $\begin{array}{l}X>3,2 \\
2,4<X \leq 3,2 \\
1,6<X \leq 2,4 \\
0,8<X \leq 1,6 \\
X \leq 0,8\end{array}$ & 4 & Excellent \\
\hline
\end{tabular}

Table 7. Results of LKPD Feasibility Assessment of DLMRs Model

\begin{tabular}{|c|c|c|c|c|}
\hline No. & Aspect & Interval Score & Score & Quality \\
\hline 1. & Content Validity & $\begin{array}{l}X>4,8 \\
3,6<X \leq 4,8 \\
2,4<X \leq 3,6 \\
1,2<X \leq 2,4 \\
X \leq 1,2\end{array}$ & 6 & Excellent \\
\hline 2. & Language & $\begin{array}{l}X>5,6 \\
4,2<X \leq 5,6 \\
2,8<X \leq 4,2 \\
1,4<X \leq 2,8 \\
X \leq 1,4\end{array}$ & 7 & Excellent \\
\hline 3. & Display & $\begin{array}{l}X>7,2 \\
5,4<X \leq 7,2 \\
3,6<X \leq 5,4 \\
1,8<X \leq 3,6 \\
X \leq 1,8\end{array}$ & 9 & Excellent \\
\hline 4. & Graphic & $\begin{array}{l}X>8 \\
6<X \leq 8 \\
4<X \leq 6 \\
2<X \leq 4\end{array}$ & 10 & Excellent \\
\hline
\end{tabular}


Jurnal Inovasi Pendidikan IPA, 5 (2), 2019 - 189

Syahmel Syahmel, Jumadi Jumadi

\begin{tabular}{cllll}
\hline No. & Aspect & Interval Score & Score & Quality \\
\hline \multirow{3}{*}{ 5. } & Using Multiple Representations & $\mathrm{X} \leq 2$ & \multirow{2}{*}{ Excellent } \\
& & $\mathrm{X}>1,6$ & \\
& $1,2<\mathrm{X} \leq 1,6$ & & \\
& $0,8<\mathrm{X} \leq 1,2$ & & \\
& $0,4<\mathrm{X} \leq 0,8$ & & \\
& $\mathrm{X} \leq 0,4$ & \\
\hline
\end{tabular}

Table 8. Result of Expert Assessment Revision

\begin{tabular}{|c|c|c|}
\hline No. & $\begin{array}{c}\text { Elements of } \\
\text { DLMRs Model }\end{array}$ & Results of Revision \\
\hline 1. & $\begin{array}{l}\text { Theoretical } \\
\text { Review }\end{array}$ & $\begin{array}{l}\text { The interrelationships of the theories underlying the development of the DLMRs } \\
\text { model is specifically described. }\end{array}$ \\
\hline 2. & Syntax & $\begin{array}{l}\text { The name of the syntax is by adding the type of representation that appears in each } \\
\text { syntax of the DLMRs model. Using multiple representations in each syntax of the } \\
\text { DLMRs model is in tabular form. This table contains all the activities of the teacher } \\
\text { and students during the learning process. Student activities in the DLMRs model are } \\
\text { characterized by using one or more multiple representations that match each syntax. }\end{array}$ \\
\hline \multirow[t]{3}{*}{3.} & Supporting & Guidelines for Lesson Plan refer to Permendikbud No. 81A of 2013, Permendikbud \\
\hline & System & No. 103 of 2014 and Permendikbud No. 22 of 2016. \\
\hline & & $\begin{array}{l}\text { Improvements to scaling and scoring techniques from KPS observation sheets and } \\
\text { curiosity. The scoring technique is the Interval Successive Method (MSI) to transform } \\
\text { the data from ordinal into the interval }\end{array}$ \\
\hline
\end{tabular}

Table 9. Result of Teachers' Response to DLMRs Model

\begin{tabular}{|c|c|c|c|c|}
\hline No. & Aspect & Interval of Score & Score & Quality \\
\hline 1. & Syntax & $\begin{array}{l}X>54,6 \\
44,2<X \leq 54,6 \\
33,8<X \leq 44,2 \\
23,4<X \leq 33,8 \\
X \leq 23,4\end{array}$ & 51,5 & Good \\
\hline 2. & Social System & $\begin{array}{l}X>33,6 \\
27,2<X \leq 33,6 \\
20,8<X \leq 27,2 \\
14,4<X \leq 20,8 \\
X \leq 14,4\end{array}$ & 30,5 & Good \\
\hline 3. & Principle of Reaction & $\begin{array}{l}X>21 \\
17<X \leq 21 \\
13<X \leq 17 \\
9<X \leq 13 \\
X \leq 9\end{array}$ & 19 & Good \\
\hline 4. & Supporting System & $\begin{array}{l}X>88,2 \\
71,4<X \leq 88,2 \\
54,6<X \leq 71,4 \\
37,8<X \leq 54,6 \\
X \leq 37,8\end{array}$ & 85 & Excellent \\
\hline 5. & Effect & $\begin{array}{l}X>12,6 \\
10,2<X \leq 12,6 \\
7,8<X \leq 10,2 \\
5,4<X \leq 7,8 \\
X \leq 5,4\end{array}$ & 12 & Good \\
\hline
\end{tabular}

Table 10. Result of students' responses to the readability of LKPD of DLMRs models.

\begin{tabular}{clcc}
\hline Aspect & Interval of Score & Score & Quality \\
\hline Readability of LKPD & $\mathrm{X}>75,6$ & 81,53 & Excellent \\
& $61,2<\mathrm{X} \leq 75,6$ & \\
& $46,8<\mathrm{X} \leq 61,2$ & \\
& $32,4<\mathrm{X} \leq 46,8$ & \\
$\mathrm{X} \leq 32,4$ & \\
\hline
\end{tabular}




\section{Jurnal Inovasi Pendidikan IPA, 5 (2), 2019 - 190}

Syahmel Syahmel, Jumadi Jumadi

\section{Main Product Revision}

Revisions to the developed products based on expert assessment are presented in Table 8.

\section{Main Field Testing}

The assessed DLMRs model and its tools on the feasibility aspect by experts are then used in limited trials to elicit teacher's responses when teaching using the DLMRs model. Teachers are allowed to teach one meeting. Then, a questionnaire is provided to assess the continuity or condition of learning in the classroom. Limited trials are also used to explore and collect students' responses related to the readability of LKPD models of DLMRs. The results of teacher and student assessments after using the DLMRs model are presented in Tables 9 and 10.

\section{Operational Product Revision}

The revision of this limited trial conducted based on an assessment or response by filling out a questionnaire that provided to 15 students of class X.4 of SMPN 1 Watopute after reading and assessing the LKPD of the DLMRs model. Stu- dents, as the subject of LKPD on the DLMRs model, also have the opportunity to suggest and comment on the improvement. Student assessment showed the result in excellent categories. Here, there is a few revision. The revision is only on spelling and experimental steps in LKPD that are less understood by students in the experiments of "Hydrostatic Pressure" and "Transport in Plants."

\section{Operational Field Testing}

This stage aims to find out the practicality and effectiveness of the DLMRs model to improve students' science process skills and critical thinking.

\section{Practicality Analysis of DLMRs Model}

An assessment of the practicality of the DLMRs model was through the responses of both teachers and students by providing a questionnaire after learning using the DLMRs model. The results of the response analysis given by teachers and students are presented in Table 11 and Table 12 .

Table 11. Analysis Results of Teacher Responses to the DLMRs Model

\begin{tabular}{|c|c|c|c|c|}
\hline No. & Aspect & Interval of Score & Score & Quality \\
\hline 1 & Syntax & $\begin{array}{l}X>54,6 \\
44,2<X \leq 54,6 \\
33,8<X \leq 44,2 \\
23,4<X \leq 33,8 \\
X \leq 23,4\end{array}$ & 55 & Excellent \\
\hline 2 & Social System & $\begin{array}{l}X>33,6 \\
27,2<X \leq 33,6 \\
20,8<X \leq 27,2 \\
14,4<X \leq 20,8 \\
X \leq 14,4\end{array}$ & 32 & Good \\
\hline 3 & Principle of Reaction & $\begin{array}{l}X>21 \\
17<X \leq 21 \\
13<X \leq 17 \\
9<X \leq 13 \\
X \leq 9\end{array}$ & 19,5 & Good \\
\hline 4 & Supporting System & $\begin{array}{l}X>88,2 \\
71,4<X \leq 88,2 \\
54,6<X \leq 71,4 \\
37,8<X \leq 54,6 \\
X \leq 37,8\end{array}$ & 88,5 & Excellent \\
\hline 5 & Effect & $\begin{array}{l}X>12,6 \\
10,2<X \leq 12,6 \\
7,8<X \leq 10,2 \\
5,4<X \leq 7,8 \\
X \leq 5,4\end{array}$ & 12 & Good \\
\hline
\end{tabular}


Jurnal Inovasi Pendidikan IPA, 5 (2), 2019 - 191

Syahmel Syahmel, Jumadi Jumadi

Table 12. Analysis Results of Student Responses to the DLMRs Model

\begin{tabular}{|c|c|c|c|c|}
\hline No. & Aspect & Interval of Score & Score & Quality \\
\hline 1. & Learning Implementation & $\begin{array}{l}X>84 \\
68<X \leq 84 \\
52<X \leq 68 \\
36<X \leq 52 \\
X \leq 36\end{array}$ & 89,3 & Excellent \\
\hline 2. & Readability of LKPD & $\begin{array}{l}X>67,2 \\
54,4<X \leq 67,2 \\
41,6<X \leq 54,4 \\
28,8<X \leq 41,6 \\
X \leq 28,8\end{array}$ & 73,1 & Excellent \\
\hline
\end{tabular}

Table 13. Mean Gain Score of KBK and KPS

\begin{tabular}{clccl}
\hline No. & \multicolumn{1}{c}{ Class } & Variable & Gain Score & \multicolumn{1}{c}{ Category } \\
\hline 1. & Experiment & KBK & 0,72 & High \\
& Control & & 0,44 & Intermediate \\
2. & Experiment & KPS & 0,6 & Intermediate \\
& Control & & 0,0 & Poor \\
\hline
\end{tabular}

Analysis of the Effectiveness of the DLMRs Model

Analysis of the effectiveness of the DLMRs model is based on data pretest and posttest of KPS and KBK. The data on the calculation results of KPS and KBK are briefly presented in Figure 2. Meanwhile, the analysis results of the increase through the gain score analysis are presented in Table 13.

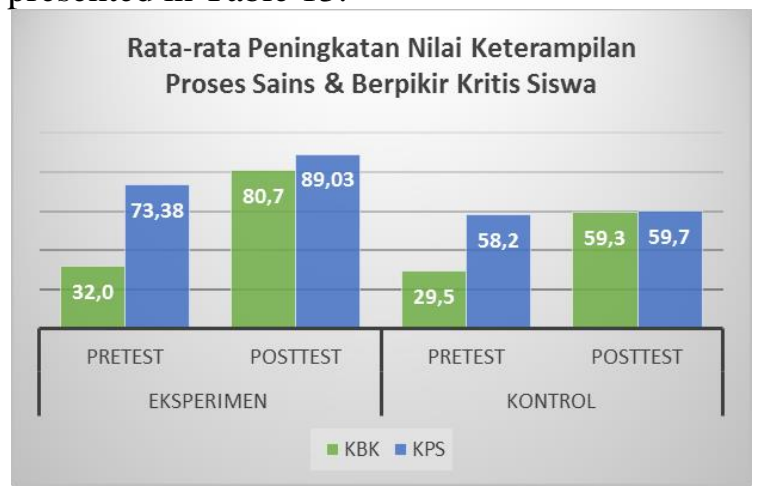

Figure 2. Average Increasing KPS and KBK

The MANOVA test conducted to find out whether there was a significant difference in increasing KPS and KBK, which were analyzed together in the experimental class and the control class, assisted by SPSS Version 21. The MANOVA test carried out when it meets the assumption test, namely the normality test and homogeneity test. The data for the test is the analysis result of the increasing scores of KPS and KBK. The output of the multivariate normality test analysis, presented in Table 14, showed the value of sig. Shapiro-Wilk and KolmogorovSmirnov for all data the consequent variables
(KBK and KPS) which are higher than the significance level $(\alpha=0.05)$. Therefore, the data distribution is normal. The homogeneity test of the variants on the dependent variable is analyzed using the Box's M Test. The analysis results of the variance-covariance homogeneity test are presented in Table 15.

Table 14. Result of Normality Test

\begin{tabular}{cccccccc}
\hline \multicolumn{8}{c}{ Tests of Normality } \\
\hline \multirow{3}{*}{ Data } & Class & \multicolumn{3}{c}{ Kolmogorov- } \\
Smirnov
\end{tabular}

Table 15. Result of Variance-Covariance Homogeneity Test

\begin{tabular}{cc}
\hline Box's Test of Equality of Covariance Matrices $^{\mathrm{a}}$ \\
\hline Box's M & 11,125 \\
F & 1,755 \\
df1 & 6 \\
df2 & 26882,239 \\
Sig. &, 104 \\
\hline
\end{tabular}

The result of Box's M Test in Table 15 showed that the significance of Box's M is 0.104, higher than the significance level $(\alpha=0.05)$. So, there is a homogeneity of variance-covariant matrices or samples were from the homogeneity population. The results of both of these prerequisite tests allow continuing to MANOVA test. 
The decision of the MANOVA hypothesis test is seen in Multivariate Tests, presented in Table 16. The value of F on Pillae Trace, Wilk Lambda, Hotelling Trace, or Roy's Largest Root.x has a significance value of 0,000 , or, smaller than 0.05 . The interpretation of the analysis results is, significant differences $n$ increasing in KPS and KBK values between students in the experimental class and the control class.

Table 16. Result of Multivariate Test

\begin{tabular}{|c|c|c|c|c|}
\hline \multicolumn{5}{|c|}{ Multivariate Tests ${ }^{\mathrm{a}}$} \\
\hline Effect & & Value & $\mathrm{F}$ & Sig. \\
\hline \multicolumn{2}{|c|}{ Intercept Pillai's Trace } & ,98 & $1562,6^{b}$ & ,000 \\
\hline \multirow{7}{*}{ Class } & Wilks' Lambda & 01 & $1562,6^{b}$ &, 000 \\
\hline & Hotelling's Trace & 79,45 & $1562,6^{\mathrm{b}}$ & ,000 \\
\hline & Roy's Largest Root & 79,45 & $1562,6^{\mathrm{b}}$ & 000 \\
\hline & Pillai's Trace & ,62 & $32,36^{\mathrm{b}}$ & ,000 \\
\hline & Wilks' Lambda & ,37 & $32,36^{\mathrm{b}}$ & ,000 \\
\hline & Hotelling's Trace & 1,64 & $32,36^{\mathrm{b}}$ & ,000 \\
\hline & Roy's Largest Root & 1,64 & $32,36^{\mathrm{b}}$ &, 000 \\
\hline
\end{tabular}

Final Product Revision

The particular last stage did not provide a fundamental improvement because the developed DLMRs model had a process of improvement in stages 1 and 2 . The revision was only to add a profile of scientists who had a role in the concept of substance pressure, attached at the end of the LKPD sheet. The revision was the advice of the teacher during the field trials.

\section{Discussion}

The final product of the particular research was the DLMRs model, Lesson Plan of DLMRs model, LKPD (Students Worksheet) of DLMRs models that are appropriate and feasible in science learning, especially on material Pressure and its Application in Daily Life. Also, assessment instruments of KBK and KPS are valid based on expert judgment. The assessment of two experts toward the DLMRs model includes an assessment of all the elements of the learning model, namely theoretical review, syntax, social system, principle of reaction, support system; and instructional and accompaniment effects. The results of the expert assessment showed that all six elements of the DLMRs model are in the "excellent" category. So, the DLMRs model is feasible to use in learning. Experts assess the lesson plan of DLMRs models based on the completeness of the components and their characteristics. The aspects of Lesson plan of DLMRs model consisted of the identity of the Lesson Plan; formulation of indicators and learning objectives; teaching material; learning methods; media and learning resources; learning steps; assessment of learning outcomes. The results of the expert judgment of the Lesson Plan of DLMRs model showed that all the criteria on the Lesson Plan are in the "excellent" category. So, the lesson plan is feasible to use in learning. Expert judgment on LKPD DLMRs models showed a "very good" category. So, the LKPD DLMRs models were feasible to use in learning on the material of Substance Pressure and Its Application in Daily Life.

The practicality aspect of the DLMRs model is assessed based on the ease of its application in learning. The learning model is practical when users (teachers and students) respond well toward the usefulness and ease of use of this DLMRs model. Based on the questionnaire given to teachers that aim to find out the teacher's response after teaching using the DLMRs model, this model was easy to implement and improve the students' KPS and KBK. The response given by the teacher to the DLMRs model includes the aspects of syntax; social system; reaction principle: support system; and instructional and accompaniment effects. The results of the teachers' responses showed the category of "good" in every aspect of the questionnaire. Students also give their responses to this DLRMs model based on their experience during the learning. The students' responses are in the "excellent" category. The responses of students are; the learning process in the classroom is very fun, helps students to understand the material better, and the students' worksheet greatly facilitates students in experiment activity, and more enthusiastic in learning. Both responses of teachers and students to the DLMRs model stated that this model was practical to use in science learning.

The developed DLMRs model may state as effective when it can significantly affect the results of formative evaluations or improve student's learning outcomes. The effective criteria for this model are on a significant increase in the score of KPS and KBK. The analysis results on the increase in KPS and KBK through gain scores indicated that the increase in the experimental class is higher than the control class. The mean KBK gain score in the experimental class was 0.72 , which means the increase was at the "high" level. Meanwhile, the mean score of the KBK gain score in the control class was 0.44 , which means the increase was at the "intermediate" level. The increase of KPS in the experimental class was at the "intermediate" level with a mean gain score of 0.6. And, the KPS in the control 


\section{Jurnal Inovasi Pendidikan IPA, 5 (2), 2019 - 193}

Syahmel Syahmel, Jumadi Jumadi

class was at the "low" level with a mean gain score of 0.0. The results of the gain score analysis provide information that there is an increase in the KBK and KPS of students in the experimental class who learn with the DLMRs model. The next analysis is the MANOVA hypothesis test which aims to find out the significant increase in the two dependent variables. The results of the MANOVA test with SPSS Version 21 are shown in the Multivariate Test table which displays the $F$ value for Pillae Trace, Wilk Lambda, Hotelling Trace, or Roy's Largest Root.x has a significance of 0,000 that is smaller than 0.05 . The results of the Multivariate Test confirm that there are significant differences in the PBK and KPS on increasing between the experimental and the control class. It influenced by the type of learning model applied by the teacher in the class. The results of the gain score analysis and the MANOVA test proved that the DLMRs model is effective in increasing KBK and KPS.

The use of the DLMRs model that is characterized by concept discovery by using multiple representations can make it easier for the student to understand the material because the science concept can be explored through several forms of representation, such as verbal, picture, physical, and mathematical representations. The DLMRs model guides students to understand the material by coherently using multiple representations; starting with verbal, picture, physical, and ending with a mathematical. In line with Leigh's findings (Leigh, 2004, pp. 41-42), students will have better concept understanding when starting with a descriptive understanding (verbal), then, proceed with pictures and diagrams, and end with mathematical equations.

Previous studies by (Namdar \& Shen, 2018, pp. 636-653), the knowledge can be organized by using multiple representations to achieve a comprehensive understanding. In another study by (Gilbert \& Treagust, 2009), the students better understand the concept by using multiple representations compared to using only one particular representation.

Activities in each syntax of the DLMR model can also help students independently find their concepts because each student in the group has the opportunity to conduct an investigation. The effect of active inquiry by students is the understanding of concepts stored in memory for a long time. This finding is supported by (Hosnan \& Sikumbang, 2014, pp. 280-291); the discovery learning model can have an impact on long-term understanding as a result of the maximum role of students. Furthermore, (Pratiwi \& Rasmawan, 2014) stated that the discovery learning model could influence the improvement of students' critical thinking skills. The application of discovery learning models also has a positive impact, such as improving science process skills (Yusuf \& Wulan, 2015).

Students who learn science by using multi representations will encourage them to optimize critical thinking of science process skills. Similar findings by (Fredlund, Airey, \& Linder, 2015), multiple representations provide opportunities to understand and communicate the acquired concepts through forms of representation. The study showed that students who learn through the DLMRs model had increased KPS and KBK compared to conventional learning models. The results are in line with the findings of (Waldrip, Prain, \& Carolan, 2010), who stated that learning science requires the practice of using multiple representations to stimulate the thinking process of the student in completing the entire set of investigations. Building a learner's concept of a particular topic or material requires forms or format of representation to block the mistake and achieve comprehensive understanding. Each student in understanding the concepts needs multiple representations. Multiple representations can guide students in learning concepts, problem-solving, using them to solve and respond to problems (Kohl, Rosengrant, \& Finkelstein, 2007).

\section{CONCLUSION}

The conclusions of this study are (a) the DLMRs model is feasible to use and implement in science learning based on the expert judgments and empirical trials, (b) the DLMRs model is efficient to apply in science learning based on the responses both given by teachers and students, and (c) the DLMRs model effectively improves students' science process and critical thinking skills.

\section{REFERENCES}

Ainsworth, S. (1999). The functions of multiple representations. Computers \& Education, 33(2-3), 131-152. https://doi.org/10.1016/S03601315(99)00029-9

Ainsworth, S. E., Bibby, P. A., \& Wood, D. J. (1997). Information technology and multiple representations: new opportunities - new problems. Journal of Information Technology for Teacher 


\section{Jurnal Inovasi Pendidikan IPA, 5 (2), 2019 - 194}

Syahmel Syahmel, Jumadi Jumadi

Education, 6(1), 93-105. https://doi.org/10.1080/147593997002000 06

Budiningsih, A. (2005). Belajar dan pembelajaran. Jakarta: Rineka Cipta.

Crain, W. (2015). Theories of development: Concepts and applications. Psychology Press.

Fredlund, T., Airey, J., \& Linder, C. (2015). Enhancing the possibilities for learning: variation of disciplinary-relevant aspects in physics representations. European Journal of Physics, 36(5), 55001. https://doi.org/10.1088/01430807/36/5/055001

Gall, M. D., Gall, J. P., \& Borg, W. R. (2007). An introduction to educational design research. East. Retrieved from www.slo.nl/organisatie/international/publi cations

Gilbert, J. K., \& Treagust, D. (2009). Multiple representations in chemical education (Vol. 4). Springer.

Goldston, M. J., \& Downey, L. (2013). Your science classroom: Becoming an elementary/middle school science teacher. SAGE Publications.

Hamid, A. A. (2011). Pembelajaran fisika di sekolah: Apa dan bagaimana pendekatan generik dan metode iqra dilaksanakan dalam pembelajaran fisika. Yogyakarta.

Hosnan, M., \& Sikumbang, R. (2014). Pendekatan saintifik dan kontekstual dalam pembelajaran abad 21: Kunci sukses implementasi kurikulum 2013. Bogor: Ghalia Indonesia.

Joyce, B. R., Weil, M., \& Calhoun, E. (2014). Models of teaching. London: Pearson Education Inc.

Kohl, P. B., Rosengrant, D., \& Finkelstein, N. D. (2007). Strongly and weakly directed approaches to teaching multiple representation use in physics. Physical Review Special Topics - Physics Education Research, 3(1), 010108. https://doi.org/10.1103/PhysRevSTPER.3. 010108

Leigh, G. (2004). Developing multirepresentational problem solving skills in large, mixed-ability physics classes. University of Cape Town. Retrieved from https://open.uct.ac.za/handle/11427/6533

Menteri Pendidikan dan Kebudayaan Republik Indonesia. Peraturan Menteri Pendidikan dan Kebudayaan Republik Indonesia
Nomor 81A tahun 2013 tentang implementasi kurikulum, Pub. L. No. 81A (2013). Indonesia.

Namdar, B., \& Shen, J. (2018). Knowledge organization through multiple representations in a computer-supported collaborative learning environment. Interactive Learning Environments, 26(5), 638-653.

https://doi.org/10.1080/10494820.2017.13 76337

National Science Teachers Association. (2003). Standards for science teacher preparation. Lincoln. Retrieved from http://digitalcommons.unl.edu/teachlearnf acpub

OECD. (2014). PISA 2015 Results: What students know and can do-student performance in mathematics. Organisation for Economic Co-operation and Development.

Pierce, R., Stacey, K., Wander, R., \& Ball, L. (2011). The design of lessons using mathematics analysis software to support multiple representations in secondary school mathematics. Technology, Pedagogy and Education, 20(1), 95-112. https://doi.org/10.1080/1475939X.2010.5 34869

Pratiwi, F. A., \& Rasmawan, R. (2014). Pengaruh penggunaan model discovery learning dengan pendekatan saintifik terhadap keterampilan berpikir kritis siswa SMA. Jurnal Pendidikan Dan Pembelajaran, 3(7). $\quad$ Retrieved from http://jurnal.untan.ac.id/index.php/jpdpb/a rticle/view/6488

Provasnik, S., Malley, L., Stephens, M., Landeros, K., Perkins, R., \& Tang, J. H. (2016). Highlights from TIMSS and TIMSS advanced 2015: Mathematics and science achievement of US students in grades 4 and 8 and in advanced courses at the end of high school in an international context (NCES 2017-002). US Department of Education. Washington, DC.: National Center for Education Statistics.

Sprianus, L. A., Sutopo, S., \& Parno, P. (2016). Strategi pembelajaran multi representasi untuk meningkatkan konsep kinematika mahasiswa semester awal. In Prosiding Semnas Pendidikan IPA Pascasarjana, Universitas Negeri Malang. Malang: Universitas Negeri Malang.

Treagust, D. F., Duit, R., \& Fischer, H. E. (2017). 


\section{Jurnal Inovasi Pendidikan IPA, 5 (2), 2019 - 195}

Syahmel Syahmel, Jumadi Jumadi

Multiple representations in physics education (Vol. 10). Springer.

Trianto, T. (2010). Model pembelajaran terpadu: Konsep, strategi, dan implementasinya dalam Kurikulum Tingkat Satuan Pendidikan (KTSP). Jakarta: Bumi Aksara. https://doi.org/2010

Waldrip, B., Prain, V., \& Carolan, J. (2010). Using multi-modal representations to improve learning in junior secondary science. Research in Science Education, 40(1),

65-80. https://doi.org/10.1007/s11165-009-9157-
6

Widoyoko, S. E. P. (2013). Evaluasi program pembelajaran: panduan praktis bagi pendidik dan calon pendidik. Yogyakarta: Pustaka Pelajar. https://doi.org/2013

Yusuf, M., \& Wulan, A. R. (2015). Penerapan model pembelajaran discovery learning menggunakan pembelajaran tipe shared dan webbed untuk meningkatkan keterampilan proses sains. Jurnal Penelitian \& Pengembangan Pendidikan Fisika, 1(2), 19-26. https://doi.org/10.21009/1.01204 